\title{
DIAGNÓSTICO INCIDENTAL DE MIGRACIÓN ASINTOMÁTICA DE DISPOSITIVO INTRAUTERINO*
}

\author{
Drs. Octavio Garaycochea ${ }^{1}$, César Rázuri P. ${ }^{2,3}$
}

1 Universidad de San Martín de Porres.

2 Servicio de Cirugía General I3. Hospital Nacional Dos de Mayo.

3 Universidad Nacional Mayor de San Marcos.

Lima, Perú.

\section{Asymptomatic far-migration of an intrauterine device into the abdominal cavity}

Paciente mujer de 57 años de edad que durante el trascurso del tratamiento de patología biliar, le es diagnosticado mediante imágenes, la presencia de una imagen sugerente de un dispositivo intrauterino (DIU) en la cavidad peritoneal lejos de su lugar de inserción.

La perforación uterina es una de las complicaciones de la inserción de un DIU, con una incidencia de 1,3 a 1,6 por $1 \cdot 000^{1}$. La migración de este a la cavidad pélvica o abdominal puede causar complicaciones importantes como infecciones del tracto urinario, dolor abdominal crónico, formación de cálculos alrededor del DIU, gangrena del intestino delgado, obstrucciones o fístulas ureterovesicales ${ }^{1,2}$. La perforación del útero por un DIU puede ser causada al momento de la inserción o cuando éste es colocado durante el puerperio, otros factores relacionados a este fenómeno son el tamaño y posición uterina, anomalías congénitas y cirugías previas ${ }^{1}$. Si bien es extremadamente rara la migración asintomática de DIU, se han reportado casos previos ${ }^{3,4}$; respecto al tratamiento, actualmente no existe un consenso si los DIU migrados asintomáticos requieren ser retirados quirúrgicamente ${ }^{4}$.

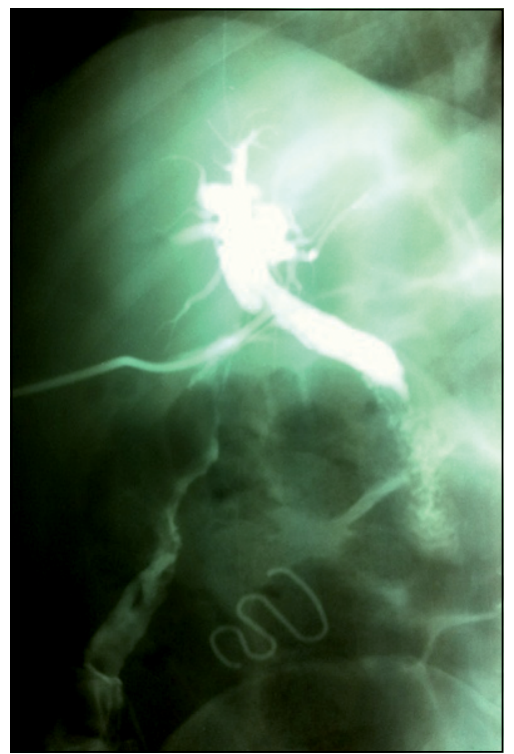

Figura 1. Colangiografía intraoperatoria en la que se evidencia una imagen opaca en forma de espiral, asemejándose a un DIU localizado en flanco derecho del abdomen.

*Recibido el 9 de abril de 2015 y aceptado para publicación el 7 de mayo de 2015.

Los autores declaran no tener ningún tipo de conflicto de intereses.

Correspondencia: Dr. Octavio Garaycochea garaycocheaoctavio@gmail.com 

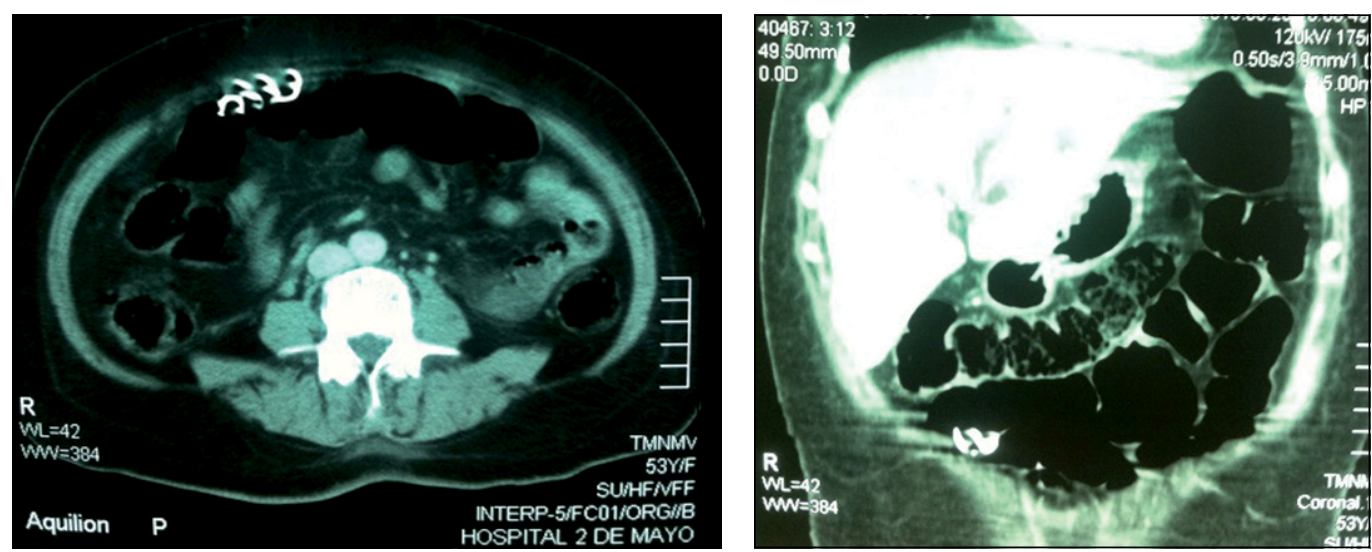

Figuras 2 y 3. Tomografía computada de abdomen que confirma la presencia del DIU cercano a la pared abdominal.

\section{Referencias}

1. Weerasekera A, Wijesinghe P, Nugaduwa N. Sigmoid colocolic fistula caused by intrauterine device migration: a case report. Journal of Medical Case Reports 2014;8:81.

2. Sun CC, Chang CC, Yu MH. Far-migrated intra-abdominal intrauterine device with abdominal pain. Taiwan
J Obstet Gynecol. 2008;47:244-6.

3. Rahnman GA, Yusuf IF. Asymptomatic missing Intrauterine Contraceptive Device found incidentally at laparotomy. J Pak Med Assoc. 2009;59:255-6.

4. Aydogdu O, Pulat H. Asymptomatic far-migration of an intrauterine device into the abdominal cavity: A rare entity. Canadian Urological Association Journal 2012;6:E134-E136. 